\title{
Reports from the 2020 CAML/ACBM Annual General Meeting
}

\section{Canadian Association of Music Libraries, Archives and Documentation Centres (CAML) L'Association canadienne des bibliothèques, archives et centres de documentation musicaux (ACBM)}

\author{
Friday, June 5, 2020, 12:30 PM \\ Online via Zoom
}
1) President's Report (Houman Behzadi)
2) By-Law Revisions (Houman Behzadi)
3) Communication Officer's Report (Marc Stoeckle)
4) CAML Review Report (Jan Guise/Jada Watson)
5) Cataloguing Committee Report (Megan Chellew)
6) Rapport SQACBM (Rachel Gagnon)
7) RILM/RISM Report
8) CAML 2020 Online Conference Program

\section{Rapport du Président de l'ACBM pour 2020}

L'ACBM a connu une année mouvementée, lançant plusieurs initiatives, et faisant face à des défis inattendus. Je voudrais, pour commencer, souligner les difficultés personnelles et professionnelles auxquelles ont fait face nos membres pendant l'épidémie de COVID-19. Les organismes canadiens d'information musicale font face - et vont continuer à faire face - aux difficultés liées au fait d'offrir des services à distance à leurs usagers. Ayant participé à plusieurs conférences en ligne au cours des dernières semaines, je constate jusqu'à quel point les professionnels de l'information participent présentement à l'effort collectif visant à redéfinir les services aux usagers dans un milieu exclusivement virtuel. Comme toujours, la musique ne manque pas de présenter des défis particuliers ; qu'il s'agisse de l'accès aux partitions à toutes sortes de questions complexes touchant les droits d'auteurs, nos problèmes n'en sont que plus évidents. Au milieu de cette crise sanitaire, nous avons pu constater, de façon remarquable, la résilience des membres de l'ACBM, qui ont démontré leur support constant pour notre association et pour la profession dans son ensemble. Je suis très reconnaissant que nous puissions nous rassembler à nouveau, même de façon virtuelle, pour afficher notre soutien envers le partage de l'information musicale, l'objectif central qui lie notre passé à un futur favorable pour les bibliothèques de musique, les centres d'archives et les centres de documentation musicaux.

Suite à l'assemblée générale annuelle (AGM) de l'année dernière à Vancouver, le Conseil d'administration a remercié les membres sortants, James Mason (agent des communications) et Katherine Penner (secrétaire). II nous a fait grand plaisir d'accueillir Marc Stoeckle et Lucinda Johnston, qui prennent respectivement la relève pour ces postes. Je souhaite exprimer toute ma 
gratitude envers notre présidente sortante, Carolyn Doi, et notre conseillère, Margaret Piper, qui terminent leurs mandats, et vont quitter le Conseil d'administration, à la fin de l'AGM d'aujourd'hui. Je tiens à remercier Carolyn pour tout ce qu'elle a fait, et pour son appui constant. Tel que mentionné dans mon précédent message publié dans le dernier numéro de la Revue de l'ACBM, grâce aux efforts de Carolyn, l'Association est maintenant mieux conscientisée face aux questions de diversité et d'inclusion. Je suis également reconnaissant à Margaret de ses efforts pour élargir la portée des critères de nos prix, ce qui nous a permis de choisir trois récipiendaires méritants.

Le Conseil d'administration s'est rencontré quatre fois cette année. En plus de nos réunions de l'automne et du printemps, et de notre réunion pré-conférence, nous avons tenu une réunion d'urgence le 23 mars, pour discuter de la réponse de l'ACBM à la décision stratégique de la Fédération des sciences humaines (ci-après la Fédération) de tenir un congrès en ligne, en collaboration avec Western University. Comme nous l'avons communiqué à nos membres le 25 mars, le Conseil d'administration a tout d'abord voté en faveur de la participation de l'ACBM à ce congrès en ligne, à condition que le soutien technologique offert par la Fédération soit adéquat. Nous avons ensuite contacté tous nos conférenciers, qui ont à leur tour répondu qu'ils étaient prêts à donner leurs présentations en ligne. Cependant, les plans de la Fédération ont changé quand Western University a décidé de se retirer, une situation inattendue dont le résultat a été l'annulation des plans de présenter le Congrès 2020 en ligne. Comme je vous l'ai dit le 3 avril, I'ACBM a continué ses discussions avec la Fédération, qui promettait de nous aider à tenir notre conférence en ligne, malgré l'annulation mentionnée plus haut. Cependant, après de nombreuses délibérations et de longues discussions, le Conseil d'administration a conclu qu'une réunion en ligne, telle qu'envisagée par la Fédération, ne fonctionnerait pas bien pour nos membres. Parmi les facteurs décisifs, on peut noter la fatigue engendrée par de longues séances devant l'ordinateur, les difficultés inhérentes aux différents fuseaux horaires, et l'alléchante possibilité d'éliminer les frais d'inscription à la fois de la Fédération et de l'ACBM. Nous avons invité nos conférenciers à se joindre à nous l'année prochaine, s'ils le peuvent.

La croissance constante de l'ACBM dépend de l'enthousiasme de ses membres, et de leur participation aux tâches requises par l'association. Je souhaite remercier toutes les personnes qui ont accepté de se porter volontaires pour s'assurer que notre gouvernance et notre organisation demeurent solides.

D'abord et avant tout, je souhaite exprimer ma reconnaissance envers le responsable du comité du programme, Alastair Boyd, et notre organisateur local, Brian McMillan, qui ont travaillé très fort, en collaboration avec nos collègues de MusCan, pour organiser une conférence " en personne » remarquable. Le programme était très dynamique, et la bibliothèque de Western University était bien préparée pour recevoir les membres de l'ACBM à la Faculté de musique Don Wright. Malgré les annulations en série et les changements de plans soudains, ils ont tous deux continué à faire 
preuve d'optimisme, et ils ont soutenu nos efforts lors de la planification de notre conférence gratuite d'une journée.

Depuis sa formation, le Groupe de travail visant le renouveau de l'ACBM s'est rencontré chaque mois, d'abord pour compléter son analyse du milieu. Le groupe de travail a employé différentes méthodes pour rassembler l'information pertinente, y compris un examen de l'histoire de l'ACBM, une comparaison avec des associations nationales similaires, un contact avec MLA et IAML, un sondage auprès des personnes abonnées à notre liste de discussion, et une discussion ouverte en ligne, qui s'est tenue le 8 avril dernier. La réunion du 5 juin est un moment important pour le groupe de travail, car nous complétons la première phase de notre tâche, et nous préparons à un exercice de planification stratégique pour déterminer la direction future que prendra l'ACBM. Le groupe de travail souhaite toujours obtenir vos commentaires, car ce sont vos idées qui, selon nous, constituent le principe directeur sous-tendant ce processus de renouvellement de l'association.

En cette période de renouveau, je veux à nouveau souhaiter la bienvenue à la nouvelle équipe de rédaction de la Revue de l'ACBM. L'équipe de rédaction a déjà commencé à planifier le prochain numéro de notre revue, et un appel officiel pour les soumissions va être publié sous peu.

Finalement, le dernier mais non le moindre, je souhaite remercier notre agent des communications, Marc Stoeckle, pour le travail accompli sur notre nouveau site web. Le site web est un outil de communication toujours en évolution, que nous allons continuer à améliorer en fonction des commentaires reçus de la part du Conseil d'administration et de nos membres.

Il est difficile de prédire à quoi ressemblera notre travail au cours des semaines et des mois à venir. Nous sera-t-il possible de tenir une réunion en personne à Edmonton en juin 2021 ? Ce qui est certain, c'est que l'ACBM va continuer à bénéficier du soutien et de la générosité de ses membres. Je constate que cette période nous a rendus plus forts et mieux conscients des obstacles qui se posent devant la participation en personne à nos conférences annuelles. Et je sais que, à l'avenir, I'ACBM va analyser des méthodes plus efficaces et plus inclusives pour continuer de faire progresser nos objectifs professionnels.

Respectueusement soumis, Houman Behzadi Président, CAML/ACBM Head Librarian, Marvin Duchow Music Library McGill University

Montréal, QC 


\section{CAML President's Report 2020}

CAML has had an eventful year, undertaking several initiatives and dealing with unforeseen challenges. I would like to begin this report by acknowledging the personal and professional difficulties our members have endured due to the COVID-19 outbreak. The Canadian music information organizations are - and will continue - dealing with the complications of providing remote services to their constituents. Having attended several online conferences over the past few weeks, I am seeing how information professionals are now participating in the collective effort of redefining user services in the online-only environment. As always, music does not fail to provide its unique challenges, from access to scores to all types of copyright complexities, our problems are now that much more tangible. Amidst the health crisis, it has been remarkable to witness the resilience of CAML members who have shown their unwavering support for our association and the profession at large. I am grateful that we are once again coming together - albeit virtually - to show our commitment to the dissemination of music information, the common goal that connects our past to an opportune future for music libraries, archives and documentation centres.

Following last year's annual general meeting (AGM) in Vancouver, the Board bid farewell to James Mason (Communications Officer) and Katherine Penner (Secretary). We were very pleased to welcome Marc Stoeckle and Lucinda Johnston to fill these positions respectively. I wish to express my gratitude to Past-President Carolyn Doi and our Board Member-at-Large Margaret Piper who will complete their mandates and rotate off the Board at the end of today's AGM. I am grateful to Carolyn for her accomplishments and continued support. As mentioned in my message published in the latest issue of CAML Review, Carolyn's efforts have raised the Association's awareness of issues surrounding diversity and inclusion. Likewise, I am thankful to Margaret for her efforts in broadening the scope of our awards criteria, which resulted in the selection of three worthy recipients.

The Board met four times this past year. In additions to our fall, spring, and pre-conference meetings, we held an emergency meeting on March 23 to discuss CAML's response to the Federation for the Humanities and Social Sciences' (henceforth Federation) strategic decision to hold an online Congress in collaboration with Western University. As communicated to the membership on March 25, the Board initially voted in favour of CAML's participation in the Federation's online congress contingent on adequate technological support from the Federation. We then contacted all presenters who in turn confirmed their willingness to present online. However, the Federation's plans changed when Western University decided to withdraw, an unexpected move that resulted in the cancellation of the online Congress 2020. As I communicated with you on April 3, CAML continued to engage with the Federation as they promised to support our online meeting regardless of the aforementioned cancellation. After much deliberation and lengthy discussions, the Board concluded that an online meeting as envisioned by the Federation would not be advantageous for the membership. The online meeting fatigue, time zone difficulties, and the attractive possibility of waiving both the Federation and CAML registration fees were 
among the deciding factors. We have invited our presenters to join us again next year should their circumstances allow.

CAML's steady growth is dependent on its members' enthusiasm and participation to carry out the work of the Association. I wish to thank all those who stepped up to ensure that our governance and overall structure remain solid.

First and foremost, I would like to express my gratitude to our Program Chair Alastair Boyd and our Local Organizer Brian McMillan. Alastair and Brian worked diligently and in close collaboration with our MusCan colleagues to prepare an outstanding in-person conference. The program was strong and the Western Music Library prepared to welcome CAML to the Don Wright Faculty of Music. Despite the series of cancellations and sudden changes of plans, both kept their optimism and supported our efforts to plan our one-day free conference.

Since its formation, the CAML Renewal Task Force has met monthly to complete its environmental scanning exercise. The Task Force has used different methods of gathering information, including an examination of CAML's history, comparisons with similar national associations, liaison with both MLA and IAML, a survey questionnaire for the listserv recipients, and an online Town Hall meeting that took place on April 8. The June 5 meeting is a pivotal moment for the Task Force as we complete the first phase of our work and prepare for a strategic planning exercise to determine CAML's future directions. The Task Force remains committed to capturing your feedback, which we view as the guiding principle of the Association's renewal process.

In this time of renewal, I once again welcome the new Editorial Team of CAML Review. The Team has already planned work on the next issue of our journal and an official call for submissions is forthcoming. Last but not least, I wish to thank our Communications Officer Marc Stoeckle for his work on our new website. The website is an evolving communication tool that we will continue to fine tune based on the feedback received from the Board and membership.

It is difficult to predict the nature of our work in the upcoming weeks and months. Will we be able to hold an in-person meeting in Edmonton in June 2021? What seems certain is that CAML will continue to benefit from its members' support and generosity. I acknowledge that this period has made us stronger and more aware of the barriers in the way of in-person attendance at our annual conferences. And I know that going forward, CAML will investigate more efficient and inclusive ways of advancing our professional goals.

Respectfully submitted, Houman Behzadi

President, CAML/ACBM

Head Librarian, Marvin Duchow Music Library

McGill University

Montreal, QC 


\section{Proposed Revisions to the Constitution and By-Laws of}

The Canadian Association of Music Libraries, Archives, and Documentation Centres (CAML)

Association canadienne des bibliothèques, archives et centres de documentation musicaux (ACBM)

*Only those articles with proposed changes are displayed

\begin{tabular}{|c|c|}
\hline Text of Current Constitution & Text of Proposed Revisions to the Constitution \\
\hline Article \# 5. BOARD & Article \# 5. BOARD \\
\hline $\begin{array}{l}\text { 5.2.3. The election results shall be announced to } \\
\text { the membership. }\end{array}$ & $\begin{array}{l}\text { 5.2.3. Elections may take place by show of hands } \\
\text { or secret ballot. Elections may be held in person } \\
\text { or using an online voting platform. } \\
\text { 5.2.4. The election results shall be announced to } \\
\text { the membership. }\end{array}$ \\
\hline Article \# 7. MEETINGS & Article \# 7. MEETINGS \\
\hline $\begin{array}{l}\text { 7.2. The date, place and agenda of the Annual } \\
\text { General Meeting shall be determined by the } \\
\text { Board. }\end{array}$ & $\begin{array}{l}\text { 7.2. Annual General Meetings } \\
\text { 7.2.1. The date, place and agenda of the Annual } \\
\text { General Meeting shall be determined by the } \\
\text { Board. } \\
\text { 7.2.2. The Annual General Meeting may be held } \\
\text { in person or virtually. }\end{array}$ \\
\hline
\end{tabular}

\section{Révisions proposées à la Constitution et aux Règlements de}

The Canadian Association of Music Libraries, Archives, and Documentation Centres (CAML)

Association canadienne des bibliothèques, archives et centres de documentation musicaux (ACBM)

*Nous n'affichons ici que les articles auxquels on propose des changements. Prière de noter que seul le texte anglais constitue le texte officiel.

\begin{tabular}{|l|l|}
\hline Texte actuel de la Constitution & Texte des révisions proposées \\
\hline Article \# 5. CONSEIL D'ADMINISTRATION & Article \# 5. CONSEIL D'ADMINISTRATION \\
\hline $\begin{array}{l}\text { 5.2.3. Les résultats des élections seront } \\
\text { annoncés aux membres. }\end{array}$ & $\begin{array}{l}\text { 5.2.3. Le vote se fait à mains levées, ou par } \\
\text { scrutin secret. Les élections peuvent avoir lieu en } \\
\text { personne ou par l'entremise d'une plateforme } \\
\text { de vote électronique. }\end{array}$ \\
\hline
\end{tabular}




\begin{tabular}{|l|l|} 
& $\begin{array}{l}\text { 5.2.4. Les résultats des élections seront } \\
\text { annoncés aux membres. }\end{array}$ \\
\hline Article \# 7. RÉUNIONS & Article \# 7. RÉUNIONS \\
\hline $\begin{array}{l}\text { 7.2. La date, le lieu, et l'ordre du jour des } \\
\text { Assemblées générales des membres seront } \\
\text { déterminés par le Conseil d'administration. }\end{array}$ & $\begin{array}{l}\text { 7.2. Assemblées générales des membres } \\
\text { 7.2.1. La date, le lieu, et l'ordre du jour des } \\
\text { Assemblées générales des membres seront } \\
\text { déterminés par le Conseil d'administration. }\end{array}$ \\
& $\begin{array}{l}\text { 7.2.2. L'Assemblée générale des membres peut } \\
\text { être tenue en personne, ou en ligne. }\end{array}$ \\
\hline
\end{tabular}

\section{Communications Officer's Report}

\section{Website}

The official CAML-ACBM website was completely redesigned and launched in late 2019. The board's feedback was incorporated, and it was made clear that the web presence will be in a constant work-in-progress type condition. Additionally, in collaboration with Membership Secretary Becky Smith, the membership registration process was updated for a more streamlined application process.

\section{Logo}

The official CAML-ACBM logo was completely redesigned and approved through conducting a survey with the association's members in good standing. The survey included three logo options that the voters had to choose from. The successful logo design was agreed on by $65.79 \%$ voters.

\section{Email}

A new general email address was created to give users an option to get in touch with CAMLACBM (contact@caml-acbm.org). So far, messages to this e-mail address are being monitored by Marc Stoeckle and Becky Smith and forwarded if necessary.

Respectfully submitted, Marc Stoeckle University of Calgary 


\section{Rapport de l'agent des communications}

\section{Site web}

Le site web officiel de l'ACBM a été complètement refondu et le nouveau site a été lancé à la fin de 2019. Les commentaires du Conseil d'administration ont été incorporés, et il est devenu clair que notre présence web devra être constamment mise à jour. De plus, en collaboration avec la Secrétaire d'adhésion, Becky Smith, le processus d'adhésion des membres a été mis à jour, permettant ainsi un processus simplifié.

\section{Logo}

Le logo officiel de l'ACBM a été complètement redessiné, et a été approuvé suite à un sondage auprès des membres en règle de l'association. Le sondage présentait trois options de logos, parmi lesquels les membres pouvaient choisir. Le dessin gagnant a été choisi par 65,79\% des membres ayant voté.

\section{Courriel}

Nous avons créé une nouvelle adresse courriel, de façon à ce qu'il soit plus facile de contacter l'ACBM (contact@caml-acbm.org). Jusqu'à maintenant, Marc Stoeckle et Becky Smith vérifient les messages reçus à cette adresse, et les envoient aux personnes concernées, si nécessaire.

Respectueusement soumis, Marc Stoeckle

University of Calgary

\section{CAML Review Report 2019-2020}

Issues Published

Volume 47, No. 2-3 (2019) was published December 12, 2019. See

https://caml.journals.yorku.ca/index.php/caml/issue/view/2316

\section{Staffing}

Cathy Martin, Lead Editor

Brian Thompson, Review Editor

Deborah Wills, Associate Editor

Megan Chellew, Associate Editor

Both the Lead and the Review Editors stepped down at the end of 2019. We wish to send a heartfelt THANK YOU to Cathy for 10 years of service as Lead Editor, and to Brian for 3 years of service as Review Editor.

As a result of these vacancies in the Board, a call for applications for a new CAML Review Lead Editor and Review Editor went out in the April 2019 issue of CAML Review, again in the December 
2019 issue, and was also posted to CANMUS-L. Although no formal applications were received, a number of people expressed interest in serving the CAML Review. Houman Behzadi, CAML President, called a meeting in March 2020 of those who had expressed interest: Carolyn Doi, Jan Guise, Brian McMillan, Nina Penner, and Jada Watson. Cathy Martin attended the meeting as a consultant to answer questions about the challenges and opportunities for CAML Review going forward. We discussed our strengths and goals for getting involved in the publication, and quickly reached a consensus: to form a new CAML Review Editorial Board. Both Deborah Wills and Megan Chellew wish to maintain their roles as Associate Editors.

\section{Lead Editors (2020-2022)}

Jan Guise (University of Toronto)

Jada Watson (University of Ottawa)

\section{Review Editors (terms tbd)}

Brian McMillan (Western University)

Nina Penner (McGill University Ph.D.)

\section{Associate Editors (terms tbd)}

Megan Chellew (McGill University)

Carolyn Doi (University of Saskatchewan)

Deborah Wills (ret'd, Wilfred Laurier Univ.)

Interim Consultant

Cathy Martin (McGill University):

The new Editorial Board has met twice since its inception and has agreed to meet monthly for the time being. We have some exciting ideas for CAML Review going forward, such as:

- Provide an outlet for "lost conference papers" that couldn't be presented because of COVID-19 cancellations

- Create a new column in the Review for features spotlighting collections and personal profiles.

- Explore publication of creative and scholarly work such as conference posters, creative writing, illustrations, essays

- Provide "teasers" of future content on CAML Web site

\section{Tentative Publication Schedule}

We will move from three issues per year to two issues per year (June and December).

- December 2020: Volume 48 "Lost Conference Papers" issue

- June 2021: Volume 49, no. 1 "COVID-19" issue

- December 2021: Volume 49, no. 2 "CAML 50th Anniversary 1971-2021" issue

If you have ideas for future issues of CAML Review, or comments on the above, please reach out to us: jada.watson@uottawa.ca and jan.guise@utoronto.ca.

Respectfully Submitted,

May 15, 2020

Jada Watson \& Jan Guise 


\section{Rapport de la Revue de l'ACBM 2019-2020}

\section{Numéros publiés}

Le volume 47, numéro 2-3 (2019) a été publié le 12 décembre 2019. Voir

https://caml.journals.yorku.ca/index.php/caml/issue/view/2316

\section{Personnel}

Cathy Martin, Rédactrice en chef

Brian Thompson, Responsable des comptes rendus

Deborah Wills, Rédactrice adjointe

Megan Chellew, Rédactrice adjointe

La rédactrice en chef et le responsable des comptes rendus ont tous les deux quitté leur poste à la fin de 2019. Nous souhaitons dire un GRAND MERCl à Cathy pour ses 10 ans de service comme rédactrice en chef, et à Brian pour ses trois années en tant que responsable des comptes rendus.

Du fait de ces départs, un appel de mise en candidature pour une nouvelle rédactrice en chef (ou un nouveau rédacteur en chef) et un nouveau (ou une nouvelle) responsable des comptes rendus a été lancé dans le numéro d'avril 2019 de la Revue de l'ACBM et à nouveau dans le numéro de décembre 2019 ; cet appel a également été publié sur la liste CANMUS-L. Bien qu'aucune candidature officielle n'ait été reçue, plusieurs personnes ont exprimé un certain intérêt. Le président de l'ACBM, Houman Behzadi, a organisé une réunion, en mars 2020, avec toutes ces personnes : Carolyn Doi, Jan Guise, Brian McMillan, Nina Penner, et Jada Watson. Cathy Martin a également participé à cette réunion en tant que consultante, pour répondre aux questions touchant les défis et les opportunités qui attendent la Revue. Nous avons discuté de nos talents respectifs, ainsi que de nos objectifs, et avons rapidement atteint un consensus : nous avons décidé de former une nouvelle Équipe de rédaction de la Revue de l'ACBM. Deborah Wills et Megan Chellew souhaitaient toutes les deux demeurer en poste en tant que rédactrices adjointes.

\section{Rédactrices en chef (2020-2022)}

Jan Guise (University of Toronto)

Jada Watson (Université d'Ottawa)

\section{Responsables des comptes rendus (mandats à déterminer) \\ Brian McMillan (Western University) \\ Nina Penner (Ph.D. de McGill University)}

\author{
Rédactrices associées (mandats à déterminer) \\ Megan Chellew (McGill University) \\ Carolyn Doi (University of Saskatchewan) \\ Deborah Wills (retraitée, Wilfred Laurier \\ University) \\ Consultante intérimaire \\ Cathy Martin (McGill University)
}

La nouvelle Équipe de rédaction s'est déjà rencontrée deux fois depuis qu'elle a été mise sur pied, et planifie pour l'instant des rencontres mensuelles. Nous avons déjà des idées emballantes pour la Revue, telles que: 
- Rassembler les " présentations de conférences disparues » qui n'ont pas pu être présentées en public, suite aux conférences annulées à cause du COVID-19.

- Créer une nouvelle chronique dans la Revue, pour mettre en valeur des collections et des individus.

- Explorer l'idée de publier des articles savants ou créatifs, comme des affiches pour conférences, des créations littéraires, des illustrations et des essais.

- Présenter un avant-goût du contenu qu'on prévoit afficher sur le site web de l'ACBM.

\section{Calendrier de publication préliminaire}

Nous prévoyons passer de trois à deux numéros par année (juin et décembre).

- Décembre 2020: Volume 48: numéro consacré aux “Présentations de conférences disparues".

- Juin 2021: Volume 49, no 1: numéro du "COVID-19"

- Décembre 2021: Volume 49, no 2: numéro du 50e anniversaire de l'ACBM, 1971-2021.

Si vous avez des idées pour de prochains numéros de la Revue de l'ACBM, ou des commentaires au sujet de ce qui précède, vous êtes invités à nous contacter : jada.watson@uottawa.ca et jan.guise@utoronto.ca.

Respectueusement soumis, Le 15 mai 2020

Jada Watson \& Jan Guise

\section{Cataloguing Committee Report}

\section{Year activities}

Megan and Andrew met with Houman Behzadi in October 2019 to discuss the current and possible future directions of the Cataloguing Committee. One idea raised was to sustain the committee as a community of best practice such as supporting institutions who are part of the NACO funnel and making contributions to the Name Authority file, or undertaking an environmental scan of current Music documentation that could be adapted for our members, at the same time trying to remain modest and focused as a committee.

The goal for this year (which has been delayed somewhat, due to the ongoing pandemic situation) is to present a report to the CAML board of the committee's renewed mandates and propose several longer-term project goals related to the charges of the Cataloguing Committee that will take the form of a 1-year pilot.

As an initial step, we wish to survey members to ask about the needs of cataloguers and librarians. 
Respectfully submitted, Megan Chellew, Andrew Senior

\section{Rapport du Comité de catalogage de l'ACBM}

\section{Activités de cette année}

Megan et Andrew ont tenu une réunion avec Houman Behzadi, en octobre 2019, pour discuter des objectifs actuels et futurs du comité de catalogage. Une des idées proposées a été de faire du comité un point de référence pour les pratiques exemplaires, pour soutenir par exemple les institutions qui font partie du « funnel » NACO et contribuent au fichier des autorités de NACO ; une autre idée serait de faire une analyse du milieu, de façon à repérer la documentation qui existe au sujet de la musique, et qui pourrait être adaptée pour nos membres, sans toutefois nous montrer trop ambitieux, et en gardant en tête les objectifs principaux de notre comité.

Notre objectif pour cette année (quelque peu retardé par la pandémie actuelle) est de présenter au Conseil d'administration de l'ACBM un rapport établissant le mandat renouvelé de notre comité, et proposant plusieurs projets à long terme liés au mandat du comité de catalogage, dans le cadre d'un projet-pilote d'un an.

En guise de première étape, nous souhaitons sonder les membres, pour leur poser des questions sur les besoins des catalogueurs et des bibliothécaires.

Respectueusement soumis,

Megan Chellew, Andrew Senior

\section{Rapport de la Section québécoise de l'ACBM pour l'année 2019}

Chaque année, pendant l'automne, la Section québécoise de l'ACBM organise une rencontre d'une journée ; cette rencontre comprend l'assemblée générale annuelle de la Section québécoise, des présentations variées, et au moins une visite ; cette journée de rencontre constitue l'essentiel des activités de la Section.

Le vendredi 22 novembre 2019 (jour de la fête de sainte Cécile, patronne des musiciens), nous avons tenu notre rencontre à la bibliothèque Webster de l'Université Concordia, à Montréal. Grâce à la présence d'une quarantaine de participants, y compris quelques étudiants, cette rencontre a été, encore une fois, un succès. Le programme de la journée, en plus de l'AGM, comprenait plusieurs moments permettant le réseautage entre collègues, des moments qui semblent toujours 
trop courts. La présentation de Michel Léonard, musicothécaire de l'Orchestre symphonique de Montréal, a été fort appréciée, tout comme celle présentée en après-midi par plusieurs de nos collègues de l'Université McGill, et portant sur l'harmonisation des collections archivistiques à la bibliothèque de musique Marvin Duchow. Une table ronde sur la préparation matérielle de la musique de chambre et d'orchestre a permis l'échange de trucs et bons procédés (un résumé de cette table ronde est d'ailleurs disponible sur le site de la section, www.sqacbm.org ). Finalement, une visite de la superbe Bibliothèque Webster, ainsi que de son "Technology Sandbox ", et un cocktail agrémenté par un trio musical formé d'étudiants de l'université Concordia, ont clôturé la journée.

Le succès de cette rencontre est encore une fois dû au travail méticuleux des membres du comité, Catherine Jolicoeur, Christiane Melançon et Kimberly White, ainsi qu'au personnel de l'Université Concordia, dont nous avons grandement apprécié l'accueil exemplaire, et qui a tout fait pour nous faciliter la vie. Le programme complet de la rencontre est affiché sur le site de la section québcoise.

Du point de vue financier, la section se porte toujours bien. En termes de membres, la section est également toujours stable, avec une quarantaine de membres (les participants à la conférence annuelle deviennent membres de la section pour l'année). Le site web est fonctionnel et à jour ; cependant, la liste de discussion n'est que peu active.

Le Conseil d'administration est actuellement composé de Rachel Gagnon, présidente, Kimberly White, vice-présidente, Christiane Melançon, trésorière, et Catherine Jolicoeur, agente de communication.

Le C.A. a déjà commencé à préparer la prochaine rencontre ; initialement prévue pour le vendredi 23 octobre 2020 à Sherbrooke, celle-ci pourrait cependant devoir, selon les circonstances, se transformer en rencontre virtuelle.

Respectueusement soumis par

Rachel Gagnon, M.B.S.I.

Bibliothécaire principale au catalogage, Bibliothèque et archives Canada

Présidente, Section québécoise de l'ACBM

Rachel.Gagnon2@canada.ca

\section{Report from the Québec Chapter of CAML for 2019}

Every year, in the fall, the Québec Chapter of CAML organizes a one-day meeting, which includes our chapter's AGM, presentations, and a visit. Together with our discussion list and web site, this generally sums up our activities for the year. 
On Friday November 22nd, 2019 (on the feast day of Saint Cecilia, patron saint of music), we held our meeting at the Webster Library, Concordia University, in Montréal. Some 40 participants (including a few students) were present, and the day was, once more, a success. The day included the AGM and several breaks for networking - moments that always seem too short. A presentation by Michel Léonard, orchestra librarian for the Orchestre symphonique de Montréal, was much appreciated, as was the presentation by several colleagues from McGill University about "Access to Memory" (AtoM) and a new approach to providing access to archival collections at the Marvin Duchow Music Library. A round table on preparation of chamber music and orchestra music allowed for an exchange of best practices (a summary of the round table is available on the section's web site, www.sqacbm.org ). The day ended with a visit of the superb Webster Library and its Technology Sandbox, and a musical cocktail, with live music provided by a trio of students from Concordia University.

Once more, the day was a great success thanks to the meticulous planning by members of our committee, Catherine Jolicoeur, Christiane Melançon and Kimberly White, and thanks also to the Concordia University staff, who welcomed us and did everything they could to help us. The complete programme is posted on the section's web site.

Financially, the Québec Chapter is still doing very well. The number of members is also stable, at around 40 members (participants to our annual conference become members for a year). Our web site is regularly updated; however our discussion list is not very active.

Presently serving on the Board are: Rachel Gagnon, President, Kimberly White, Vice-President, Christiane Melançon, Treasurer, and Catherine Jolicoeur, Communication Officer.

We have started planning our next annual meeting; the plan was to have it on Friday, October $23^{\text {rd }}$, 2020, in Sherbrooke; however, current circumstances might force us to transform it into a virtual meeting.

Respectfully submitted by

Rachel Gagnon, M.B.S.I.

Senior Cataloguing Librarian, Library and Archives Canada

President, Québec Chapter of CAML

Rachel.Gagnon2@canada.ca 
CAML Online Conference, Friday, June 5, 2020

La conférence en ligne de l'ACBM, le vendredi 5 juin 2020

\section{Program / programme:}

\begin{tabular}{|c|c|c|}
\hline 10:30 EST & Optional & Greetings / Salutations \\
\hline 11:00 EST & Session 1 & $\begin{array}{l}\text { CAML Renewal Task Force Session A ( } 60 \\
\text { minutes): Presentation of the Task Force } \\
\text { environmental scanning exercise } \\
\text { Session A du Groupe de travail visant le } \\
\text { renouveau de l'ACBM ( } 60 \text { minutes): } \\
\text { Présentation de l'exercice d'analyse } \\
\text { environnementale du groupe de travail }\end{array}$ \\
\hline 12:00 EST & Break / Pause & $(10 \mathrm{~min})$ \\
\hline $12: 10 \mathrm{EST}$ & Session 2 & $\begin{array}{l}\text { Annual General Meeting (60 minutes) } \\
\text { Assemblée générale annuelle (60 minutes) }\end{array}$ \\
\hline $1: 10 \mathrm{EST}$ & Break / Pause & $(10 \mathrm{~min})$ \\
\hline $1: 20 \mathrm{EST}$ & Session 3 & $\begin{array}{l}\text { Hot Topics Session (60 minutes) } \\
\text { Session sur les sujets d'actualité ( } 60 \text { minutes) }\end{array}$ \\
\hline 2:20 EST & Break / Pause & $(10 \mathrm{~min})$ \\
\hline 2:30 EST & Session 4 & $\begin{array}{l}\text { CAML Renewal Task Force Session B ( } 60 \\
\text { minutes): Discussion regarding the Task Force } \\
\text { strategic planning exercise } \\
\text { Session B du Groupe de travail visant le } \\
\text { renouveau de l'ACBM ( } 60 \text { minutes): } \\
\text { Discussion concernant l'exercice de } \\
\text { planification stratégique du groupe de travail }\end{array}$ \\
\hline 3:30 EST & Optional & Social Hour / Moment de socialisation \\
\hline
\end{tabular}

